\title{
シンポジウムロ今, 注目すべき食品媒介病原体
}

-Food Pathogens to Be Paid Attention Now

\section{病原性エルシニアの疫学と検査法}

Epidemiology of Pathogenic Yersinia and Their Detection Method

福島博

（元 島根県保健環境科学研究所）

Hiroshi Fukushima

(Shimane Prefectural Institute of Public Health and Environmental Science, Nishihamasada, Matsue 690-0122)

\section{1.はじめに}

わが国において Yersinia が原因菌として確認された 最初の集団感染は 1972 年に静岡県で発生した Yersinia enterocolitica による食中毒様事例 ${ }^{4}$ である. その後の相 次ぐ集団事例の発生により, 1982 年にY.enterocolitica は食中毒原因菌に指定されている。これより半世紀前の 1925 年から 1951 年に泉熱 24$)$ と呼称され発熱と発疹を 主徵とする猩紅熱様発疹性疾患の集団事例が全国で多数 発生し，その原因は不明のままであった，その後，1977 年から西日本で相次いで発生した Y. pseudotuberculosis による集団感染事例之の比較研究により泉熱の原 因はY.pseudotuberculosis であったことが明らかにさ れ38)，わが国には古くからY. pseudotuberculosis が流 行していたことが示唆された.

病原性 Yersinia にはY. enterocolitica, Y. pseudotuberculosis と $Y$. pestis の 3 菌種が含まれるが，19 世 紀後半に微生物学の基本的技術が確立され，ヒ卜から最 初に分離された Yersinia は病原性の最も強いY. pestis で第三次ペストパンデミーのおり 1894 年の香港でのこ とである ${ }^{48)}$. Y. pseudotuberculosis は 1910 年にヨー ロッパで少年の回盲部リンパ節，1913 年にわが国で敗 血症による死亡例加ら分離された。病原性の弱いY.enterocolitica はアメリカ合衆国で 1934 年に農夫の顔面 の膿瘍，1939 年に小児の腸炎から分離された。その後 多くの非病原性 Yersinia が環境材料から分離され, Yersinia はその病原性状の脱落により病原性の弱い菌 種へ変異したと半世紀以上にわたり信じられていた。し かし, 病原性 3 菌種の house-keeping gene の MLST (multilocus sequence typing) 解析により Yersinia 属 の進化の過程が比較解析され ${ }^{2)}$, Yersinia 属の祖先は大 腸菌や Salmonella とほほ同時期の 4100 万年〜 1 億 8600 万年前の白亜紀に腸内細菌科の共通祖先菌汃 分

焉690-0122 松江市西浜佐陀町 582-1
化したことが 1999 年に報告された。それによると，地 球上に出現した非病原性 Yersinia は 40 190 万年前の 第四紀に腸管上皮細胞への侵入因子 (inv, ail 遺伝子) を 他菌種から獲得し病原性 Yersinia の祖先となる菌群へ 進化した。 その後, 個々に病原性プラスミド (pYV) を獲 得することによりマクロファージに抵抗し腸管上皮で増 殖できる病原性 Y. enterocolitrica とY. pseudotuberculosis へと進化したと考えられている. Y. pestis が Y. pseudotuberculosis から分化した時期は意外と遅く氷河 期後期の 2 万年前と第一次ペストパンデミーでペスト の存在が初めて確認された 1500 年前との間であったろ うと推測されている。これは哺乳動物の腸管に定着する Y. pseudotuberculosis がノミの腸管に定着できる能力 などを獲得し ${ }^{8)}, Y$. pestis までに進化するのに長い道の りを必要としたことを示している. 現在, Yersinia 属に は病原性 3 菌種と非病原性菌種の Y. intermedia と $Y$. frederikusenii, Y. kristensenii, Y.ruckeri, Y. aldovae, $Y$. rohdei, Y. bercovieri, Y. mollaretii, Y. aleksiciae ${ }^{41)}, Y$. massiliensis ${ }^{31)}$ の 17 菌種が含まれている. Yersiniaの 進化には生化学的性状や病原性状はもとより宿主動物が 密接に関与している. 病原性菌種が保有する $\mathrm{pYV}$ 上に は小腸上皮細胞への接着と侵入に関与する yadA 遺伝子 等の病原性に関わる遺伝子のほかに，かつて $\mathrm{V}$ 抗原と 呼ばれ Yersinia の感染防御抗原であある LcrV が存在 する。病原性 Yersinia に感染（保菌）した個体には細胞 性免疫が成立し，再度暴露されてもその菌種や血清群に 関係なく感染することはなく, Yersinia 感染は 1 回に限 られる。本現象により, 病原性 Yersinia は自然界におい てあたかむ“棲み分け”をしているかのように分布して おり，Yersinia の疫学を理解するのに重要な鍵となる.

\section{2. 病原性 Yersinia の性状と病原性}

腸内細菌科, Yersinia 属 17 菌種のうちヒトに対し病 原性を持つ菌種には Y. pestis, Y. pseudotuberculosis と Y. enterocolitica があり, 後 2 菌種は食水系感染症の原 
表 1. Y. pseudotuberculosis のヒトへの病原性と血清群，遺伝子型，自然界の分布

\begin{tabular}{|c|c|c|c|c|c|c|c|c|c|c|c|c|}
\hline \multirow{2}{*}{ 遺伝 } & \multicolumn{5}{|c|}{ 病原因子保有状況 } & \multirow{2}{*}{$\begin{array}{l}\text { pYV } \\
\text { 保有率 }\end{array}$} & \multirow{2}{*}{$\mathrm{MF}^{\mathrm{a})}$} & \multirow{2}{*}{ 病原性または病原型 } & \multicolumn{2}{|c|}{ 血清群の地域分布 } & \multirow{2}{*}{$\begin{array}{c}\text { 極東地域での患者 } \\
\text { からの分離状 } \\
\text { (血清群) }\end{array}$} & \multirow{2}{*}{ 保菌動物 } \\
\hline & HPI & R-HPI & YPMa & YPMb & YPMc & & & & 欧米 & 極東 & & \\
\hline 1 & + & - & + & - & - & 56 & + & 病原性 & & $1 \mathrm{~b}, 3,5 \mathrm{a}, 5 \mathrm{~b}, 15$ & $\begin{array}{l}\text { 日本 } 1 \text { 株 (3), } \\
\text { 韓国 } 3 \text { 株 (1b, 15) }\end{array}$ & 野生動物 \\
\hline 2 & + & - & - & - & - & 49 & + & 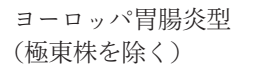 & $1 \mathrm{a}, 1 \mathrm{~b}$ & $1 \mathrm{a}, 3,5 \mathrm{~b}, 13,14$ & 中国 1 株 (3) & $\begin{array}{l}\text { 家畜, ペット, } \\
\text { 野生動物 }\end{array}$ \\
\hline 3 & - & - & + & - & - & 77 & + & 極東全身感染型 & & $\begin{array}{c}1 \mathrm{~b}, 1 \mathrm{c}, 2 \mathrm{a}, 2 \mathrm{~b}, 2 \mathrm{c} \\
3,4 \mathrm{a}, 4 \mathrm{~b}, 5 \mathrm{a}, 5 \mathrm{~b} \\
6,7,10,15\end{array}$ & $\begin{array}{l}\text { 日本, 韓国, } \\
\text { ロシア } 663 \text { 株 } \\
\text { (1c, } 7 \text { を除く) }\end{array}$ & $\begin{array}{l}\text { 家畜, ペット, } \\
\text { 野生動物 }\end{array}$ \\
\hline 4 & - & - & - & + & - & 0 & - & 非病原性 (Y. similis) & & $\begin{array}{c}1 \mathrm{~b}, 5 \mathrm{a}, 5 \mathrm{~b}, 6,7 \\
9,10,11,12\end{array}$ & & モグラ, ノネズミ \\
\hline 5 & - & + & - & - & + & 89 & - & ヨーロッパ弱病原型 & 3 & 3 & 日本 1 株 (3) & 家畜 （主にブタ） \\
\hline 6 & - & - & - & - & - & 50 & + & 病原性 & $\begin{array}{c}1 \mathrm{~b}, 2 \mathrm{a} \\
2 \mathrm{~b}, 3,5 \mathrm{a}\end{array}$ & $\begin{array}{l}1 \mathrm{~b}, 2 \mathrm{a}, 2 \mathrm{~b}, 2 \mathrm{c}, 3 \\
4 \mathrm{a}, 4 \mathrm{~b}, 5 \mathrm{a}, 5 \mathrm{~b}, 6 \\
7,10,11,13,15\end{array}$ & $\begin{array}{l}\text { 日本 } 11 \text { 株 } \\
(2 \mathrm{a}, 3,4 \mathrm{a}, \\
5 \mathrm{~b})\end{array}$ & $\begin{array}{l}\text { 家畜, ペット, } \\
\text { 野生動物 }\end{array}$ \\
\hline
\end{tabular}

a)メリビオースの醗酵性

因となり, 感染,ミの吸血により感染するペストの原因 菌であるY. pestis と区別されている. 両菌種は生化学 性状, 血清型と病原因子の保有状況などにより型別され る.

\section{$2.1 Y$. pseudotuberculosis（表 1)}

$Y$. pseudotuberculosis は Y. pestis と遺伝学的には同 一の菌種である.Y. pseudotuberculosis には O 抗原 33 種が確認され， 1〜 15 血清群と 6 亜群を含む 21 血清群 (1a, 1b, 1c, 2a, 2b, 2c, 3, 4a, 4b, 5a, 5b, 6, 7, 8, 9, 10, 11, $12,13,14,15)$ に分類される。主に野生動物に保菌され, 家畜やペットからあ分離されることがある. 本菌は後述 する病原因子の High-pathogenicity island (HPI), Right hand part of HPI (R-HPI) ŁY. pseudotuberculosis-derived mitogen (YPM) の YPMa, YPMb, YPMc の組合せにより 6 遺伝子型に分類される ${ }^{21)}$.

(1)遺伝子型 1: YPMa と HPI を保有し，ヒトに病原性 を示す. 血清群 $1 \mathrm{~b}, 3,5 \mathrm{a}, 5 \mathrm{~b}, 15$ に属し, 極東アジアに 分布する. 患者 4 名からの分離が確認されている.

(2)遺伝子型 2 (ヨーロッパ腸炎病原型)：HPI のみを保 有し, 腸炎や腸間膜リンパ節炎を起こす欧米における主 要なクローンである. 血清群 $1 \mathrm{a}, 1 \mathrm{~b}$ に属し，ヨーロッパ およびヨーロッパの住民が移住したオセアニア，南北ア メリカに分布する，本遺伝子型には極東アジア，主に中 国で分離される血清群 3,5b の一部と血清群 13,14 屯属 し, 数株が確認されている.

(3)遺伝子型 3 (極東全身性病原型)：YPMa のみを保有 し, 腸炎や腸間膜リンパ節炎, さらに発疹などの多彩な 全身症状を起こす極東アジアにおける主要なクローンで ある. 血清群 1b, 2a, 2b, 2c, 3, 4a, 4b, 5a, 5b, 6, 10, 15 に 属し，極東アジアに分布し欧米には分布していない。

(4)遺伝子型 4: YPMb のみを保有し, ヒトに病原性を 示さない. メリビオース非分解性で血清群 $1 \mathrm{~b}, 5 \mathrm{a}, 5 \mathrm{~b}, 6$, 7, 9, 10,11, 12 に属し, わが国でモグラなどの野生動物 と環境に広く分布している.

(5)遺伝子型 5(ヨーロッパ弱病原型)：R-HPI と
YPMc を保有し，ヒトに対する病原性は弱いが腸炎を起 こす。メリビオース非分解性の血清群 3 が属し, 欧米の ブタに分布する血清群 3 はすべて本遺伝子型である。わ が国でも一部地域のブ夕に分布し，患者 1 名が確認され ている.

(6)遺伝子型 6: HPI とYPM のいずれも保有しないが, 患者加らあ分離される．血清群に関係なく世界的に分布 する。

\subsection{Y. enterocolitica（表 2)}

Y. enterocolitica は生物型, 血清型, ファージ型によ り型別されるが，ファージ型別は一般には用いられな い. 生物型は $1 \mathrm{~A}, 1 \mathrm{~B}, 2,3,4,5$ に分類される ${ }^{45)} . \quad Y$. enterocolitica およびその類似菌種には $\mathrm{O}$ 抗原 76 種が 報告されている。Y. enterocoliticaの菌型と病原性や地 域性には密接な関連があり, 病原性により 5 群に分けら れる.

(1)生物型 1A: 血清型 O1〜O76

エスクリンを加水分解しヒトに病原性を示さず，自然 界に広く分布する.

(2)生物型 1B: 血清型 O8, O4, 32, O13, O18, O20, O21 エスクリンを加水分解せず，リパーゼ，インドール陽 性でヒトに病原性を示す。血清型 08 とアメリカ合衆国 で報告された血清型 $\mathrm{O} 4,32, \mathrm{O} 13, \mathrm{O} 18, \mathrm{O} 20, \mathrm{O} 21$ などの American strains が含まれる. 生物型 1B は鉄の取り込 みに関与する HPI を持つ強毒株で, 菌血症を起こすこ とがある. 1980 年代にアメリカ合衆国で多くの感染症 が報告されたが，今ではほとんど報告されていない。わ が国では1980年代後半から東日本で報告が増加 し23,39)，近年になって全国で発生が報告されるように なった．ブタや野生動物が保菌する．わが国とアメリカ 合衆国に分布する菌株の遺伝子型は異なっている ${ }^{22)}$.

(3)生物型 2: 血清型 O5, 27, O9

エスクリンを加水分解せず，リパーゼ陰性，インドー ル陽性でヒトに病原性を示す。血清型 O5, 27 は主に北 米に分布し，わが国であ分離される。インドール産生が 
表 2. 病原性 Yersinia の確認性状

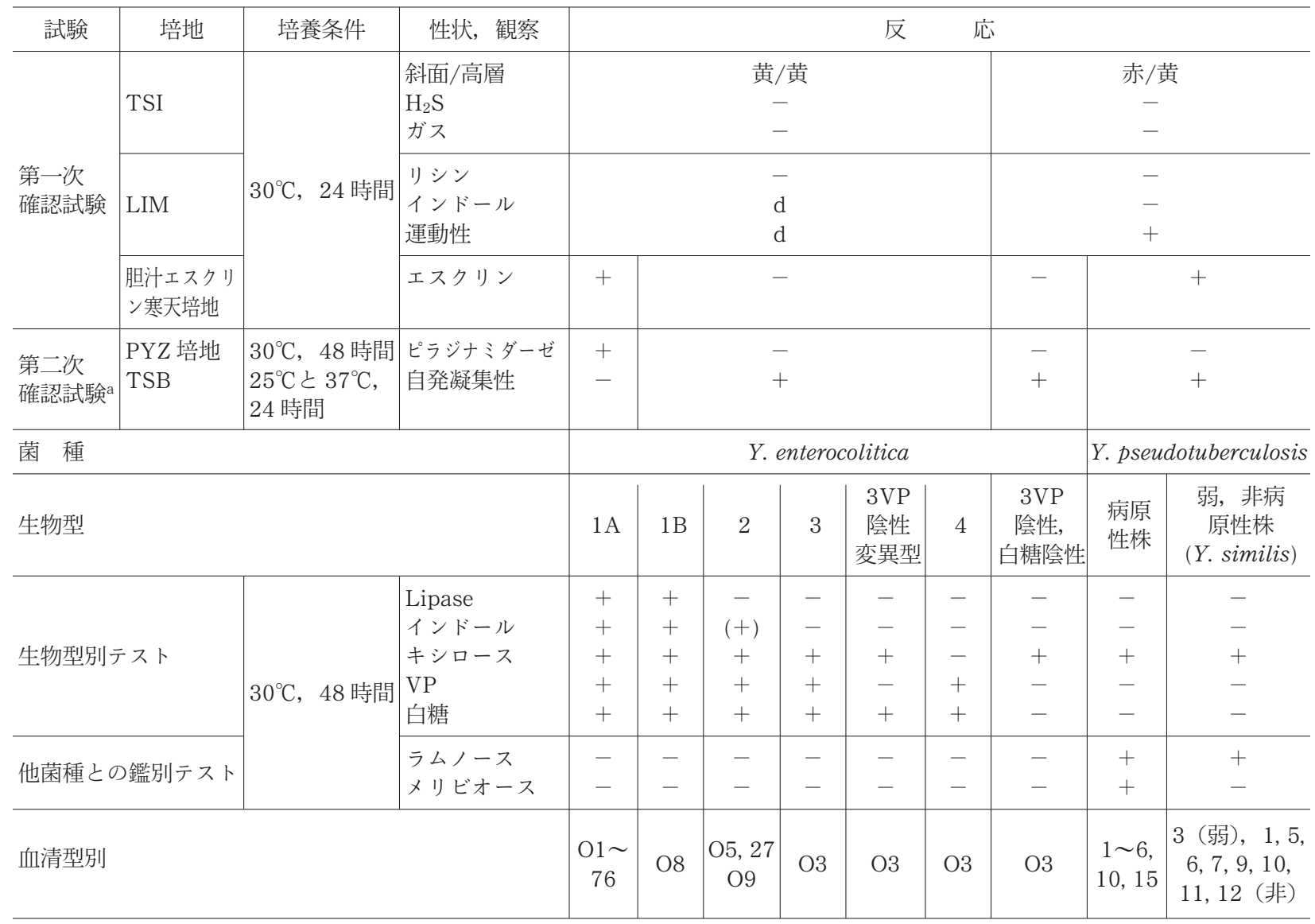

弱く生物型 3 に分類される菌株にはL-トリプトファン を増量し試験するとよい，血清型 O9 は中国やヨーロッ パに多く分布するが，近年わが国で屯患者から分離され ている ${ }^{32)}$ 、ヨーロッパでは胃腸炎のほかに関節炎の原因 として注目されたことがある。主にブタが保菌する.

(4)生物型 3, 4: 血清型 O3

エスクリンを加水分解せず，リパーゼ，インドール陰 性でヒトに病原性を示す。胃腸炎を起こし，主にブタが 保菌する。血清型 O3 のうち欧米に分布するキシロース 陰性の生物型 4 は欧米から豚肉とともにわが国に輸入 され，1980 年代前半まで広く分布した。いっぽう，中国 大陸に分布するキシロース陽性の生物型 $3 \mathrm{VP}$ 陰性变異 型もほぼ同時期に台湾から豚肉とともに輸入され，その 後徐々に分布を拡大し, 1980 年代後半には血清型 O3 の大半を占めるに至った ${ }^{16,29)}$. また，その起源は明らか でないが簡易同定キットでY. kristensenii と誤同定さ れやすい生物型 $3 \mathrm{VP}$ 陰性・白糖陰性の血清型 O3 が 1990 年代に入り分離されるようになった ${ }^{17,30)} .1980$ 年 代に多く発生した集団事例の多くは生物型 4 による。

(5)生物型 5: 血清型 O2, 3

エスクリンを加水分解せず，硝酸塩還元，オルニチン 陰性でフランスでノウサギから分離されたが，ヒトへの 感染は報告されていない。

\section{3. 発症機序と病原因子 ${ }^{6,42)}$}

経口的に摂取されたY. enetrocolitica と Y.pseudotuberculosis は, 小腸に達するとパイエル板の $\mathrm{M}$ 細胞 へ接着, 侵入し速やかに粘膜下に侵入, 基底膜に達する. これには染色体上の inv および ail 遺伝子によりコード されたInvasin およびAil (Attachment-invasion locus) と pYV上の yadA 遺伝子によりコードされた YadA (Yersinia adherence A) などの外膜蛋白が関与す る。マクロファージによる食菌を受けるが，TNF- $\alpha$ など のサイトカイン産生抑制によって殺菌作用に抵抗，増殖 し, 回腸末端炎を起こす。腸粘膜基底部の $\mathrm{Ca}^{2+}$ に乏し い環境 $\left(37^{\circ} \mathrm{C}\right)$ で増殖した菌は $\mathrm{pYV}$ 上の少なくとも 11 種類の yop 遺伝子により産生されるYops ( Y ersinia outer membrance proteins) を菌体外へ放出する. その うち YopE は宿主細胞やマクロファージを破戒する細 胞毒を生成し, YopH と同様にマクロファージの貪食作 用に抵抗するが，やがて好中球により殺菌され，健常者 では限局性炎症で自然治癒することが多い，それを回避 し抗領食作用が続く間は組織や血中で増殖する。特に, パイエル板が密集する回腸末端部ではその炎症に加え, 隣接する腸間膜リンパ節の炎症を起こし，しばしば虫垂 炎之誤診される。感染から発症までの潜伏期間は長く 3〜 7 日である. 免疫機能に異常のない健常者では限局 
性炎症で自然治瘉することが多いが，エイズのような免 疫機能低下者（特にY.pseudotuberculosis）では血中に 流入し菌血症を起こすこともある。

Yops の産生を調整する蛋白質のうちの Lcr (low calcium response) V はかつてV 抗原と呼ばれ Yops の 産生に必須な因子で, Yersinia の感染防御抗原でああ る. Y. pestis, Y. pseudotuberculosis おょび Y. enterocolitica に感染した個体は再度 Yersinia の病原株に暴露 されてもその菌種や血清群に関係なく感染は阻止され, Yersinia 感染は 1 回に限られる.この再感染阻止の現象 は, マウス抢よびラット，ノネズミ，飼育豚を用いた実 験ならびに飼育豚の観察で確認されている3,14,43).

Y.pestis, Y.pseudotuberculosis の欧米株之Y.enterocolitica 生物型 $1 \mathrm{~B}$ 血清群 $\mathrm{O} 8$ はHPI 持っ強毒 Yersinia で, HPI を構成する $f y u \mathrm{~A}$ とirp2 遺伝子は感 染過程に必要な鉄イオンの菌体内への取り込みに関与す る. HPI 保有株はしばしばヒトに敗血症を引き起こす7).

わが国を含む極東アジアに分布するY.pseudotuberculosis 遺伝子型 1 と 3 はスーパー抗原活性を持つ YPM を産生し, T 細胞の過剩活性化およびサイトカイ ンの過剩産生を促し, 発疹, 結節性紅斑, 関節炎, 急性 腎不全などの全身症状の発現に関与する ${ }^{1,44}$. YPM は スーパー抗原活性を持つ YPMa と持たない YPMb およ びYPMcに分けられ，それぞれ $y p m A, y p m B, y p m C$ 遺 伝子にコードされている。 ypmA 遺伝子はわが国や極東 ロシアで分離された菌株に確認されるが, 欧米株は保有 しない211.

\section{Yersinia の疫学と生態}

わが国における Yersinia 感染症は図 1 に示すように, Y. enterocolitica 血清型 O3 感染症は地域に関係なく広 範に発生しているが，Y. enterocolitica 血清型 O8 感染 症は東日本で, Y. pseudotuberculosis 感染症は西日本で 多く見られ，それぞれの地域における野生動物における 保菌状況之密接な関係がある.

\subsection{Y. pseudotuberculosis}

わが国には中国，韓国，極東ロシアなどに分布する遺 伝子型 3 (極東全身性病原型) のさまざまな血清群が山 間部の野生動物に広く分布し, 家畜, ペットからも分離 される。これらの菌群は水河期にユーラシア大陸東岸か らの動物の移動により持ち込まれたと考えられており, ヨーロッパに分布する遺伝子型 2（ヨーロッ八腸炎病原 型）は分布していない. Y. pseudotuberculosisには多く の哺乳類打よび鳥類が感染するが，本菌による感染症が 確認されたのは 1913 年に Saisawa が敗血症による死 亡例から本菌を分離し, 世界で最初に本菌が七トに感染 することを証明したときである。本菌感染症の報告が多 い西日本の山間部では秋から春にかけての寒冷な時期に ノネズミの約 3\%, 小型野生動物を捕食する夕又キの 15 33\%から分離され ${ }^{13)}$, ヒ上へはこの時期に野生動物
の粪便に污染された環境水等を介し感染する (図 2). 本 菌感染症は回腸末端炎, 下痢症などの腸管感染, 敗血症, 結節性紅斑など多彩な病像を示すが，水系感染による集 団発生では猩紅熱様の発熱と発疹を主徵とし，1925 年 から 1951 年の間には泉熱之呼称された集団感染がほぼ 全国で 94 例報告され総患者数 4,751 名にも及んだ. 1977 年から 1991 年の間には井戸水などの未殺菌水や 学校給食を原因とした 15 集団事例が報告され総患者数 2,603 名に及んだが，その後は報告されていない，小児 下痢症からの分離率は地域によって異なるが，山間地域 に扔ける上水道の普及之過疎化や少子高齢化により減少 している. 1980 年代に多くの症例か報告された倉敷中 央病院における検査データでも 1981 年からの 14 年間 における検出率は $2.6 \%$ であるが，1995 年以降は $0.4 \%$ に激減している(図 3 ).

わが国では第三次ペストパンデミーの 1890 年から 1921 年の間に香港からの 37 隻のペスト船の入港に伴 いペスト感染ネズミが港湾都市へ上陸し ${ }^{33)} ， 1899$ 年か ら 1926 年の 28 年間にペスト患者が 2,905名（死者 2,420 名) 発生し, ペスト感染ネズミは 24,528 匹を数え たが，ペストの流行は神戸，横浜などの港湾都市の周辺 に限られ，日本全土へは拡大しなかった。これは山間部 に生息するげっ歯類が Y. pseudotuberculosis に感染し, Yersinia に対する免疫を獲得していたことによると考 えられる。しかし, アメリカ合衆国西海岸へ到達した $Y$. pestis はプレリードッグなどの野生動物に感染し定着し た。これは野生動物に広く分布していたY. enterocolitica 生物型 $1 \mathrm{~B}$ 血清型 $\mathrm{O} 8$ の LcrV の構造が他の菌 型とは異なり Y. pestis の感染を阻止できなかったこと による.

\section{$4.2 Y$. enterocolitrica ${ }^{11)}$}

Y. ernterocolitrica は 1934 年にアメリカ合衆国で初 めて発見されたが，その菌型は現在世界に広く流行して いる血清型 O3 ではなく, 生物型 $1 \mathrm{~B}$ 血清型 O8 であっ た。本菌型のアメリカ合衆国での流行は 1970 年代前半 まで見られた。 ヨーロッパ諸国では 1960 年代に入り生 物型 4 血清型 O3 による胃腸炎が流行した。これは冷蔵 庫の普及とほぼ一致し, 本菌感染症の増加は冷蔵庫など の低温環境でも増殖する本菌の生物学的特性や冷蔵生野 菜を用いたサラ夕゙などの食習慣の普及によるところが大 きいと考えられている34). Y. enterocolitrica は病原性 3 菌種のうちで病原性が最も弱く, 動物のうち主にブ夕に 不顕性感染し, 污染豚肉や二次污染した食品などを介し ヒトに感染する．ヒトへの感染は年間を通じ見られるが 夏期に多い (図 2). 本菌は食肉に供される約 6 力月齢の ブ夕の腸内容や扁桃の約 $20 \%$ から検出されるが40), 養 豚場における本菌の分布はこれをはるかに上回る。本菌 は養豚場で豚房の床などを介しブ夕に感染し, 感染豚群 からは十数週間にわたり翼便とともに排泄するが，感染 豚の腸管内に抢ける Yersinia に対する免疫の成立と之 

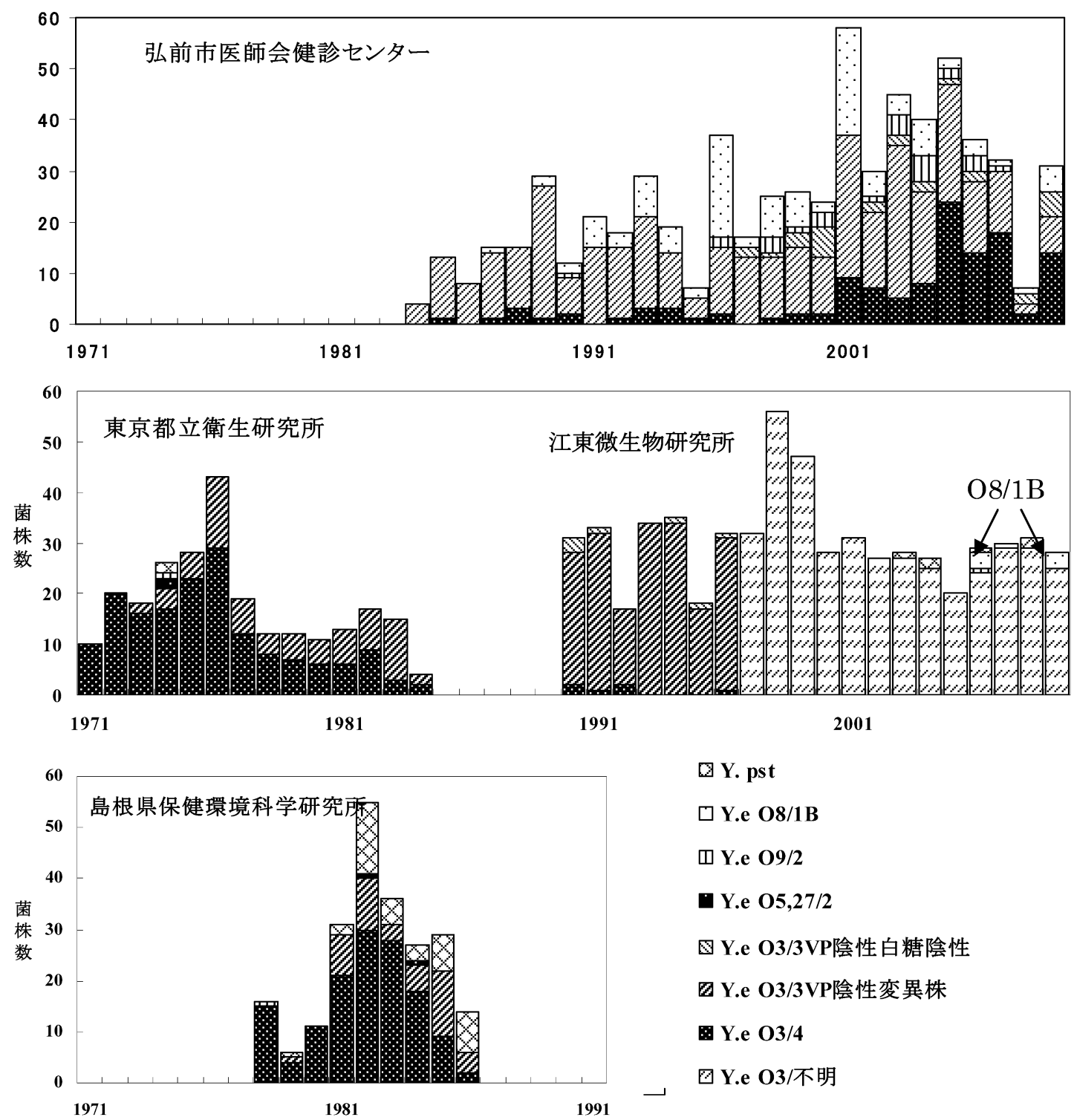

O.pst

$\square$ Y.e 08/1B

m Y.e 09/2

Y.e $05,27 / 2$

因Y.e O3/3VP陰性白糖陰性

Z Y.e O3/3VP陰性変異株

Y.e 03/4

Ⓨ.e O3/不明

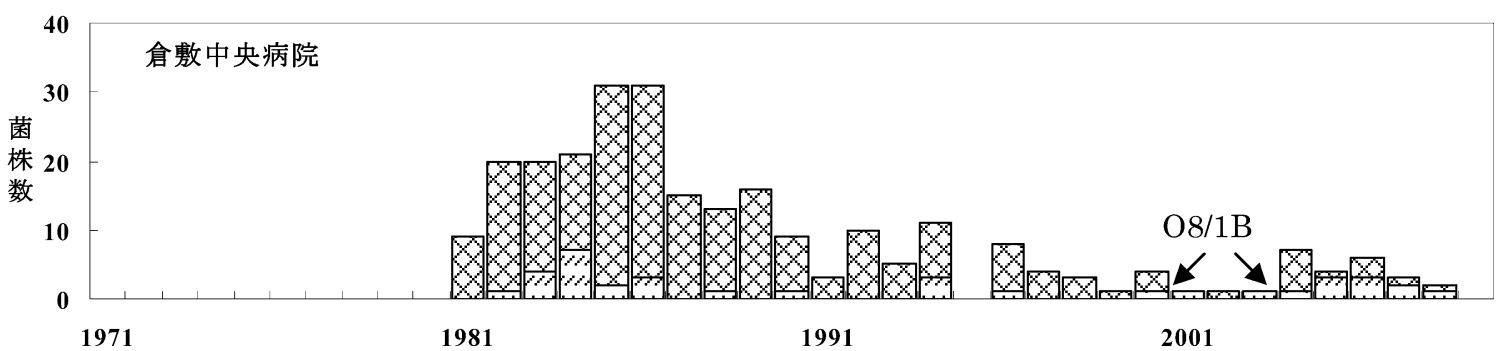

図 1. わが国の 5 検査機関におけるエルシニアの検出状況

(患者検査デー夕の一部は江東微生物研究所微生物検査室，弘前市医師会健診センター，倉敷中央病院検査科からの提供）

あに排泄されなくなる ${ }^{19)}$. 感染が養豚場で若齢豚に起 こった場合には本菌は出荷時の約 6 力月齢のブタの体 内からは除去されと畜場ではほとんど検出されないが, 感染が出荷間近いブタに起こった場合には感染豚が出荷 され, 食肉の污染源となる.ペット動物も本菌を保菌し, 1970～80 年代の保菌調査ではイヌの 5〜 6\% おょびネ コの $1 \sim 2 \%$ からの分離が報告されたが18,47)，ペット フードが普及したここ 20 年間のデータはほとんどな
い. 生物型 $1 \mathrm{~B}$ 血清型 $\mathrm{O} 8$ は野生動物からも検出され, Y. pseudotuberculosis 之同様に野生動物の糞便に污染 された環境水等を介しヒトへ感染する22).

生物型 4 血清型 O3 はヨーロッパとヨーロッパ諸国の 人々が家畜を伴い移住した南北アメリカ大陸, 南アフリ カ，オーストラリア大陸に広く分布している。特に有袋 類が生息していたオーストラリアやニュージーランドへ は18 世紀後半から19 世紀前半にかけてのヨーロッパ 


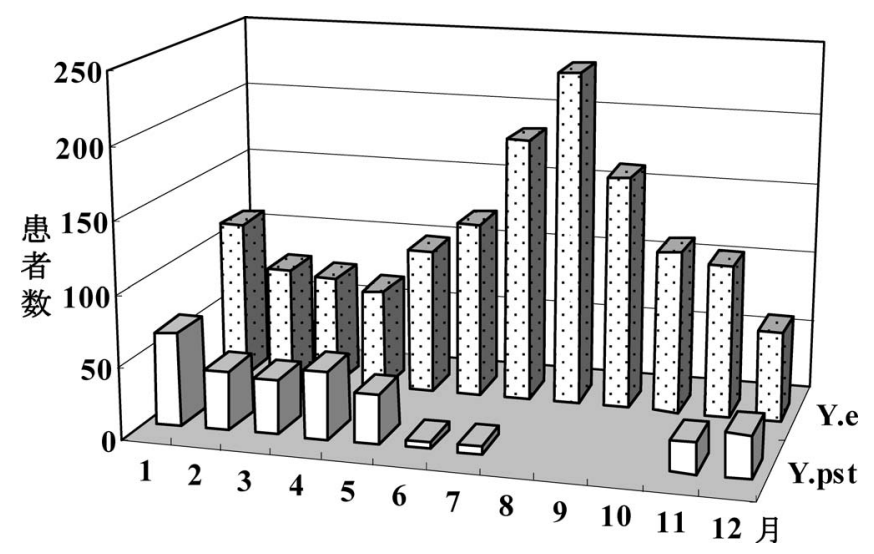

図 2. 下痢症患者からのエルシニアの月別検出状況
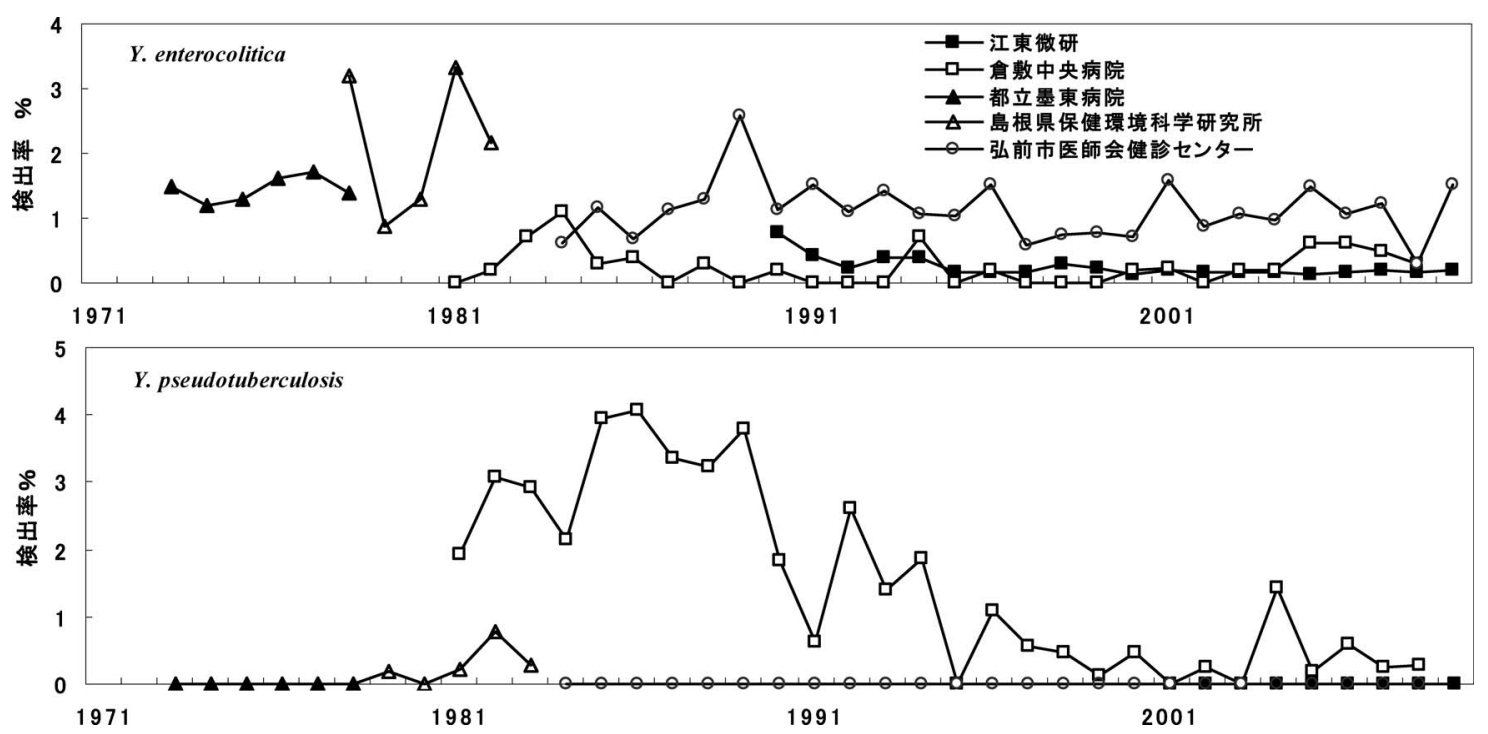

図 3. わが国における下痢症患者からのエルシニアの検出率の推移

や南アフリカからの移民によりヒトや家畜, 愛玩動物之 ともに持ち込まれた。 北アメリカへも同様にして伝播さ れ，アメリカ合衆国では 1970～1980 年代に養豚の振興 のためヨーロッパから多くのブタが輸入され，ヨーロッ パ型のファージ 8 を持つ生物型 4 血清型 O3 がブタに広 く分布した.このころから生物型 $1 \mathrm{~B}$ 血清型 $\mathrm{O} 8$ による 感染症が減少していった。その後，1980～1990 年代に カナダから肉豚や肥育豚が大量に輸入されることによ り, カナダ型のファージ 9B を持つ生物型 4 血清型 $\mathrm{O} 3$ が飼育豚に広まった6).このように, Y. enterocoliticaの 生誕地から他の地域への伝播には豚肉やブ夕の輸出が大 きく関わっており，わが国においても例外ではない。

わが国における豚肉輸入とブタおよび患者から分離さ れるY. enterocoliticaの菌型の推移を図 4 に示す.わが 国においても 1950 年以降に欧米からの種豚輸入の再開 により養豚業の振興が図られ, 豚肉の国内生産量は増加 したが，食糧事情の好転に伴う豚肉消費量の増加に追い つかず 1968 年には北アメリカ, 1972 年には北欧, 台湾 からの豚肉の輸入が開始された。輸入開始 3 年後の 1971 年には生物型 4 血清群 O3 による感染症が初めて
報告され，1972 年には集団食中毒事例が相次いで発生 した。 1980 年代に入ると台湾からの豚肉の輸入量の増 加に伴い, 台湾に分布する生物型 $3 \mathrm{VP}$ 陰性変異型・血 清型 O3 のブタと患者から分離頻度が増加し, 1990 年 代にはわが国で分離される本菌の大半を占めるに至っ た。ところが，1997 年の台湾での口蹄疫の発生による 台湾からの豚肉輸入の中止に伴う欧米からの輸入量の増 加により 2000 年以降生物型 4 血清型 O3 による感染症 が増加の傾向にある。

生物型 2 血清型 O5, 27 は世界に広く分布している が，特に北アメリカにおけるブタにおける保菌率が高 く, 1990 年代にはアメリカ合衆国で Y. enterocolitica 感染症の約 $20 \%$ 占めたと報告されている6). アメリカ 合衆国からの輸入豚肉から分離されたことあある. ヨー ロッパや日本ではブタの保菌率は低く, 感染症の発生頻 度は極めて低い。

生物型 2 血清型 O9 は主にヨーロッパと中国に分布す る. 当初から北ヨーロッパを中心に報告され, 1980 年 代に入り中部ヨーロッパでも感染症が増加し，イギリス では本菌感染症に占める割合が 1983 年の $2 \%$ から 

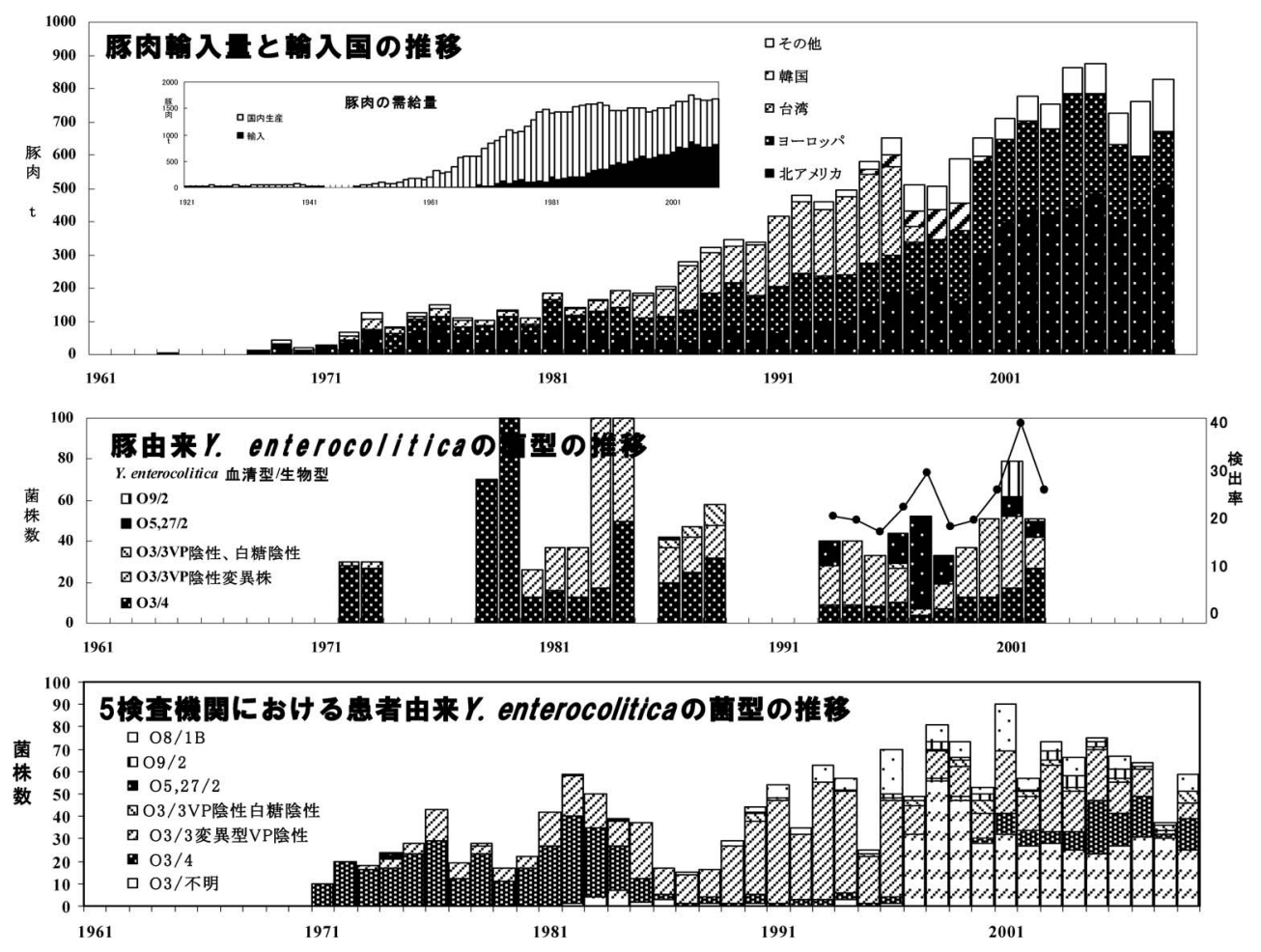

図 4. わが国における豚肉輸入とブ夕および患者から分離されるY. enterocolitica の菌型の推移

1988 年には $44 \%$ までに増加した ${ }^{37)} .1984$ 年には中国 から神戸港に輸入され，ブルセラ抗体陽性を示したラク 夕゙の筫便から分離された。 1985 1987 年の中国におけ るY. enterocolitica に関する全国調査で本血清型は主に 中国の内陸部でブタとイヌ, ネズミ, トリから分離され, 多くの小児下痢症の散発事例㧍よび集団発生事例が報告 されている28. 1997〜1999 年の中国内陸部の寧夏回族 自治区に打ける調査では漢民族の農村で古くから飼育さ れている在来種のブ夕，農家周辺に生息する小型觢歯類 とイヌから分離された。わが国においては本血清型によ る小児下痢症患者が 1974 年に最初に報告され，その 後, 患者とブ夕, 豚肉, イヌから数株ずつ分離されたが, 近年になって患者からの分離頻度が増加の傾向にある。 飼育豚が保菌する Y. enterocolitica の菌型の变遷は畜産 物生産国からのブタや豚肉の輸入に大きく影響されてき たが，2002 2003 年には西日本の養豚場で一過性に本 血清型が分離され, 中国からの農産物や稲菜などの輸入 により持ち込まれた可能性が示唆された。

生物型 1B 血清型 O8 による感染症は青森県弘前地方 で 1990 年に最初に報告されたが23)，その後の報告によ り 1987 年にはすでに症例が確認され，東日本を中心に 多くの患者が発生していることが明らかになった ${ }^{39}$. 血 清型 O8 が流行する青森県の山間部におけるノネズミの 調査では，6，8 月の温暖な季節にノネズミが血清型 O8 に感染していることが確認されており，ヒトへの感染は 主に温暖な時期に野生動物の糞便に污染された沢水など の未滅菌水を介し起こっていると考えられる22). 近年で は奈良県でのリンゴサラダによる集団食中毒, 沖縄での
川での水遊びによる感染等, 全国で発生が報告されるよ うになった。本血清型の病原性は他の菌型よりも強く, 野ネズミなどの野生動物にも感染し，Y.pseudotuberculosis 之同様に野生動物の糞便に污染された環境水を介 しヒトへ感染する.

\section{5. 検查方法}

\section{1 菌分離方法}

\subsection{1 臨床検体}

下痢便やその他の臨床材料からの分離培養は日常の粪 便検査に用いられる DHL 寒天, SS 寒天で十分である. しかし, 一般の腸内細菌之異なり $37^{\circ} \mathrm{C}$ での 1 夜培養で はほとんどの菌株は微小集落しか形成しないので，見逃 されやすい，むし 1 夜培養で他の病原菌らしいものがな いときは，さらに培養を続けて 48 時間後に観察する. 食中毒検查では Y. enterocolitica の選択性を高めたセフ スロジンーイルガサンーノボビオシン (CIN) 寒天が広く使 用されている. $37^{\circ} \mathrm{C}$ で培養された菌では病原性プラスミ ドが脱落することがあり，原因菌の病原性の確認には $25 \sim 30^{\circ} \mathrm{C}$ 培養で分離された菌株を用いる.

\section{1 .2 食品および環境検体}

\subsubsection{1 直接培養}

食品等の夾雑菌が混在する試料から Yersinia を効率 的に分離するには, 食品, ふき取り液, 水, 糞便の試料 液を直接アルカリ処理した後, 選択分離培地に塗布す る9). アルカリ処理法は, Yersinia が他のグラム陰性桿 菌よりあアルカリに強く抵抗する性状を利用した選択方 法である ${ }^{5}$. 特に Pseudomonas が多く存在する試料では 
分離効果が著しく高まるが，Y. enterocolitica の病原株 と非病原株を選択することはできない. 検体 $0.3 \mathrm{~m} l$ に $0.75 \% \mathrm{KOH}$ 加生理食塩液（または $0.5 \%$ 食塩水溶液）を $0.3 \mathrm{ml}$ 加えて 30 秒間混和後, その一白金耳を分離培地 に塗布する．ただし，30 秒以上の処理はYersiniaの死 滅をもたらすので，注意を要する.

\subsubsection{2 増菌培養}

病原性 Yersinia を選択的に増菌する方法はいまだ確 立されていないが, Yersiniaの低温増殖性を利用した低 温増菌法が広く用いられている。検体に M/15 リン酸緩 衝液 $(\mathrm{PBS})$ を 10 倍量加え, 冷蔵庫 $\left(4 \sim 9^{\circ} \mathrm{C}\right)$ で $3 \sim 4$ 週 間おく低温増菌法である ${ }^{36)}$. 特に, 水やふき取り液のよ うに栄養分の少ない試料には $0.25 \%$ ペプトン・ $0.25 \%$ マンイトール添加 PBS (PMP) などの発育支持物質を添 加した増菌培地が用いられる15)。選択増菌法について室 温増菌法や 2 段階増菌法などが検討されているが, 非病 原株の旺盛な増殖を抑制し病原Yersinia を選択的に増 菌する確実な方法はいまだない。したがって, 食中毒発 生の際の原因追及や疫学調査にはPBSによる低温増菌 法を用い， 1 週ごとに増菌液をアルカリ処理し分離培養 する.

\subsubsection{3 分離培養}

Yersiniaの分離培地としてはマンニトールの発酵を 指標とした CIN 寒天が広く用いられるが, 病原株と非 病原株の鑑別は難しく, 变法 VYE (Virulent Yersinia enterocolitica) 寒天 ${ }^{10)} の$ 併用が好ましい. 変法 VYE 寒 天は CIN 寒天 $1 \mathrm{~L}$ にスクリン $0.5 \mathrm{~g}$ と $5 \%$ クンン酸鉄 アンモニウム水溶液 $10 \mathrm{~m} l$ を添加し調製する. 試料およ び増菌培養のアルカリ処理液の一白金耳を寒天平板に塗 布し, $30^{\circ} \mathrm{C}, 24$ 時間培養する. 食中毒事例の検査には標 準菌株を両培地に対照培養し, 比較釣菌することが大切 である. CIN 寒天培地にはすべての Yersinia がマン ニット発酵性の赤色集落を形成するため非病原性 Yersinia との鑑別は難しい. 变法 VYE 寒天では病原性 Y. enterocolitica はエスクリン非分解性の赤紫色でやや 隆起した直径 $1 \mathrm{~mm}$ 程度の集落, Y. pseudotuberculosis はエスクリン分解性の暗褐色の露滴状集落を形成する が, 非病原性 Yersinia はエスクリン分解性の暗褐色を 帯びた比較的大きい集落を形成し鑑別は容易である．Y. kristensenii はエスクリン非分解性の赤紫色集落を形成 するので鑑別培養を必要とする。食品を污染する菌種の うち Pseudomonas, Proteus, Serratia などの菌種がこれ らの培地に発育するが, これらは CIN 寒天でピンクか ら白色の大きな集落を形成する。また，これらの多くは アルカリ処理により除去される。しかし，Yersiniaの非 病原株はアルカリ処理により除去されることなく, 变法 VYE 寒天で暗褐色を帯びた大きい集落を形成し，培地 全体が暗褐色となり病原株を分離できなくなるので，増 菌培養液は薄めに塗布することが大切である。したがっ て, CIN 培地にマンニトール発酵性の赤色集落と变法
VYE 寒天にエスクリン非分解性の赤紫色集落が発育し た際には病原性 Y. enterocolitica を疑い，これらの集落 を対象とし 1 平板当たり少なくとも数個ずつ釣菌して 確認培養する.

\section{2 同定}

Yersinia の同定は生化学性状検査によって行う. 病原 性 Yersinia の同定手順を表 3 に示す.Yersinia の同定 では第一次確認試験の LIM 培地でのリシン陰性が最む 重要な力ギとなる。リシン陰性で TSI 寒天の斜面部が黄 色を呈する菌群のうちエスクリン陰性のものは病原性 Y. enterocolitica と判定する. TSI 寒天の斜面部が赤色 を呈する菌群のうちエスクリン陰性のあのにはY.enterocolitica 生物型 $3 \mathrm{VP}$ 陰性・白糖陰性, 血清群 O3 が 含まれる。なお，Y. enterocolitica 生物型 $3 \mathrm{VP}$ 陰性・白 糖陰性は簡易同定キットで Y. kristensenii と誤って同 定されるので注意が必要である。第二次鑑別試験で pyrazinamidase 陰性と自発凝集性陽性の菌株は病原性 Y. enterocolitica と判定する. Pyrazinamidase の酵素 活性は Y. pseudotuberculosis と病原性 Y. enterocolitica では陰性, 非病原株では陽性となる。このテストは染色 体性の病原性と相関があることから，Y. enterocolitica の生物型にも採用されるほど重要な性状で, Yersiniaの 検査には欠くことができない. 病原性 Yersinia の新鮮 分離株の多くは約 $45 \mathrm{MDa}$ の病原プラスミドを保有し, 液体培地で $37^{\circ} \mathrm{C}$ 培養すると外膜蛋白を産生し自発凝集 することから，プラスミド性病原因子の決定には簡単に できる自発凝集性の試験が広く用いられている ${ }^{26)}$.しか し, 長期間保存した株や $37^{\circ} \mathrm{C}$ 培養した菌株では病原プ ラスミドが脱落し, 凝集しないことがある. 病原性 $Y$. enterocolitica と同定された菌株はリパーゼ，VP 反応， キシロース, 白糖分解能などを追加し生物型別を行う. なお，生物型 2 にはインドール産生が弱いあのがあり， LIM 培地に L-トリプトファンを $2 \mathrm{~g} / \mathrm{L}$ 添加し試験する。 pyrazinamidase 産生テスト用培地 ${ }^{25)}$ に接種し，28〜 $30{ }^{\circ} \mathrm{C}$ で 48 時間培養後, $1 \%$ 硫酸第一鉄アンモニウム $1 \mathrm{~m} l$ 加え, 15 分後に赤褐色を呈するものを陽性とする.

\section{3 血清型}

Y. enterocolitica と同定された菌株は市販の診断用抗 血清（デンカ生研）を用いてスライド凝集反応で型別を 行う。診断用抗血清には病原血清群がセットされている が，これらの血清に凝集が見られても，病原性に関わる 生化学性状を示さないものは病原性 Y. enterocolitica と しない.

Y. pseudotuberculosis と同定された菌株は，必要に応 じて市販診断用血清 (デンカ生研) で血清群を決定する. 市販血清には血清群 1, 2, 3, 4, 5, 6 がセットされており, 血清群 7〜15 の型別と血清群 $1,2,4,5$ の亜型の型別は できない.

\section{4 迅速検査法}

Yersinia の病原因子は染色体および pYV にコードさ 
れているが, pYVが脱落した菌株は病原性を欠くこと から，PCRによる迅速検査法の標的遺伝子としては $\mathrm{pYV}$ 上の yadA 遺伝子が広く用いられてい $3^{20,27,35,46)}$

\section{謝辞}

貴重な患者検査デー夕の提供をいただいた(株)江東微 生物研究所微生物検査室, 弘前市医師会健診センター, 倉敷中央病院検査科の諸先生に深謝いたします.

\section{参考文献}

1) Abe, J., Takeda, T., Watanabe, Y., Nakao, H., Kobayashi, N., Leung, D. Y. M. and Kohsaka, T.: Evidence for superantigen production by Yersinia pseudotuberculosis. J. Immunol., 151, 4183-4188 (1993).

2) Achtman, M., Zurth, K., Morelli, G., Torrea, G., Guiyoule, A. and Carniel, E. : Yersinia pestis, the cause of plague, is a recently emerged clone of Yersinia pseudotuberculosis. Proc. Natl. Acad. Sci. U.S.A., 96, 14043-14048 (1999).

3) Alonso, J. M., Vilmer, E., Mazigh, D. and Mollaret, H. H.: Mechanisms of acquired resistance to plague in mice infected by Yersinia enterocolitica O3. Current Microbiol., 4, 117-122 (1980).

4) Asakawa, Y., Akahane, S., Kagata, N., Noguchi, M., Sakazaki, R. and Tamura, K.: Two community outbreaks of human infection with Yersinia enterocolitica. J. Hyg., 71, 715-723 (1973).

5) Aulisio, C. C., Mehlman, I. J. and Sanders, A. C.: Alkali method for rapid recovery of Yersinia enterocolitica and Yersinia pseudotuberculosis from foods. Appl. Environ. Microbiol., 39, 135-140 (1980).

6) Bottone, E. J.: Yersinia enterocolitica: The charisma continues. Clin. Microbiol. Rev., 10, 257-276 (1997).

7) Carniel, E.: The Yersinia high-pathogenicity island. Int. Microbiol., 2, 161-167 (1999).

8) Carniel, E.: Evolution of pathogenic Yersinia, some lights in the dark. Adv. Exp. Med. Biol., 529, 3-11 (2003).

9) Fukushima, H.: Direct isolation of Yersinia enterocolitica and Yersinia pseudotuberculosis from meat. Appl. Environ. Microbiol., 50, 710-712 (1985).

10) Fukushima, H.: New selective agar medium for isolation of virulent Yersinia enterocolitica. J. Clin. Microbiol., 25, 1068-1073 (1987).

11) 福島 博: Yersinia enterocolitica. 食品由来感染症と食 品微生物. 中西寿男, 丸山務 (監修), p. 315-334, 中央 法規出版，東京 (2009).

12) 福島 博：Yersinia pseudotuberculosis. 食品由来感染 症と食品微生物. 中西寿男, 丸山 務 (監修), p. 334346. 中央法規出版, 東京 (2009).

13) Fukushima, H. and Gomyoda, M.: Intestinal carriage of Yersinia pseudotuberculosis by wild birds and mammals in Japan. Appl. Environ. Microbiol., 57, 1152-1155 (1991).
14) Fukushima, H., Ito, Y. and Saito, K.: Ecological study of Yersinia enterocolitica. III. Cross- protection against fecal excretion between $Y$. enterocolitica serovars 3 and 5, 27 in pigs. Vet. Microbiol., 9, 383-389 (1984).

15) Fukushima, H., Saito, K., Tsubokura, M. and Otsuki, K.: Yersinia spp. in surface water in Matsue, Japan. Zbl. Bakt. Hyg., I. Abt. Orig. B, 179, 235-247 (1984).

16) Fukushima, H., Tsubokura, M., Otsuki, K. and Kawaoka, Y.: Biochemical heterogeneity of serotype O3 strains of 700 Yersinia strains isolated from humans, other mammals, flies, animal feed, and river water. Current Microbiol., 11, 149-154 (1984).

17) Fukushima, H., Maruyama, K., Omori, I., Ito, K. and Kaneko, S.: Isolation of sucrose-negative Yersinia enterocolitica biotype 3 serotype $\mathrm{O} 3$ strains and their pathogenicity. Current Microbiol., 17, 199-202 (1988).

18) Fukushima, H., Nakamura, R., Iitsuka, S., Ito, Y., and Saito, K.: Presence of zoonotic pathogens(Yersinia spp., Campylobacter jejuni, Salmonella spp., and Leptospira spp.) simultaneously in dogs and cats. Zbl. Bakt. Hyg., I. Abt. Orig. B, 181, 430-440 (1985).

19) Fukushima, H., Nakamura, R., Ito, Y., Saito, K., Tsubokura, M. and Otsuki, K.: Ecological study of Yersinia enterocolitica. I. Dissemination of Y. enterocolitica in pigs. Vet. Microbiol., 8, 469-483 (1983).

20) Fukushima, H., Kawase, J., Etoh, Y., Sugama, K., Yashiro, S., Iida, N. and Yamaguchi, K.: Simultaneous screening of 24 target genes of foodborne pathogens in 35 foodborne outbreaks using multiplex real-time SYBR green PCR analysis. Int. J. Microbiol., Article ID 864817 (2010).

21) Fukushima, H., Matsuda, U., Seki, R., Tsubokura, M., Takeda, N., Shubin, F. N., Paik, I. K. and Zheng, X. B.: Geographical heterogeneity between Far East and Western countries in prevalence of the virulence plasmid, the superantigen Yersinia pseudotuberculosis-derived mitogen and the high-pathogenicity island among Yersinia pseudotuberculosis strains. J. Clin. Microbiol., 39, 3541-3547 (2001).

22) Hayashidani, H., Ohtomo, Y., Toyokawa, Y., Saito, M., Kaneko, K., Kosuge, J., Kato, M. and Ogawa, M.: Potential source of sporadic human infection with Yersinia enterocolitica O8 in Aomori Prefecture, Japan. J. Clin. Microbiol., 33, 1253-1257 (1995).

23) Ichinohe, H., Yoshioka, M., Fukushima, H., Kaneko, S. and Maruyama, T.: First isolation of Yersinia enterocolitica serotype $\mathrm{O} 8$ in Japan. J. Clin. Microbiol., 29, 846-847 (1991).

24）泉 仙助，矢ヶ崎徳蔵，杉下延郎：最近金沢市内に流行 せる一種の猩紅熱様発疹性熱性病に就いて。坚科雑誌, 347, 667-689; 348, 862-882 (1929).

25) Kandolo, K. and Wauters, G.: Pyrazinamidase activity in Yersinia enterocolitica and related organisms. J. Clin. Microbiol., 21, 980-982 (1985).

26) Laird, W. J. and Cavanaugh, D. A.: Correlation of autoagglutination and virulence of yersiniae. J. Clin. Microbiol., 11, 430-432 (1980). 
27) Lantz, P. G., Knutsson, R., Blixt, Y., Abu Al-Soud, W., Borch, E. and Radstrom, P.: Detection of pathogenic Yersinia enterocolitica in enrichment media and pork by a multiplex PCR: A study of sample preparation and PCR-inhibitory components. Int. Food Microbiol., 45, 93-105 (1998).

28) 陸 桂珍, 賈 明和, 李 功恵, 張 見秋, 蔡 潤河: 我 国耶氏菌基本特性和病原性研究. 小腸結腸耶氏菌科学論 文汒一編, p. 113-117, 全国小腸結腸耶氏菌科研協作組 (1985-1987).

29) Maruyama, T.: Yersinia enterocolitica infection in humans and isolation of the microorganism from pigs in Japan. Contr. Microbiol. Immunol., 9, 48-55 (1987).

30) 東出正人, 行方千佳, 金子誠二：糞便由来 Yersinia enterocolitica 血清型 O3 菌の各種性状. 日本臨床微生物学 雑誌, 8, 16-20 (1998).

31) Merhej, V., Adékambi, T., Pagnier, I., Raoult, D. and Drancourt, M.: Yersinia massiliensis sp. nov., isolated from fresh water. Int. J. Syst. Evol. Microbiol., 58, 779-784 (2008).

32) Moriki, S., Nobata, A., Shibata, H., Nagai, A., Minami, N., Taketani, T. and Fukushima, H.: Familial outbreak of Yersinia enterocolitica serotype O9 biotype 2. J. Infect. Chem., 16, 56-58 (2010).

33）森田秀實：日本の検疫所におけるペスト防疫の歴史. メ ディヤサークル，40，9-16 (1995).

34) Mollaret, H. H.: Fifteen centuries of yersiniosis. Contr. Microbiol. Immunol., 13, 1-4 (1995).

35) Nakajima, H., Inoue, M., Mori, T., Itoh, K., Arakawa, E. and Watanabe, H.: Detection and identification of Yersinia pseudotuberculosis and pathogenic Yersinia enterocolitica by an improved polymerase chain reaction method. J. Clin. Microbiol., 30, 2484-2486 (1992).

36) Paterson, J. S. and Cook, R.: A method for the recovery of Pasteurella pseudotuberculosis from feces. J. Path. Bacteriol., 85, 241-242 (1963).

37) Prentice, M. B., Cope, D. and Swann, D. A.: The epidemiology of Yersinia enterocolitica infection in British Isles 1983-1988. Contrb. Microbiol. Immunol., 12, 1725 (1991).

38) Sato, K., Ouchi, K. and Taki, M.: Yersinia pseudotuberculosis infection in children, resembling
Izumi fever and Kawasaki syndrome. Pediat. Infect. Dis., 2, 123-126 (1983).

39）齋藤雅明, 山口美佳子, 豊川安延, 大友良光, 金子誠二, 丸山務: 青森県弘前地区におけるYersinia enterocolitica 血清型 O8 感染症（1984 1991). 感染症学雑 誌, 68, 960-965 (1994).

40) Shiozawa, K., Akiyama, M., Sahara, K., Hayashi, M., Nishina, T., Murakami, M. and Asakawa, Y.: Pathogenicity of Yersinia enterocolitica biotype 3B and 4, serotype $\mathrm{O} 3$ isolates from pork samples and humans. Contr. Microbiol. Immunol., 9, 30-40 (1987).

41) Sprague, L. D. and Neubauer, H.: Yersinia aleksiciae sp. nov. Int. J. Syst. Evol. Microbiol., 55, 831-835 (2005).

42) Salyers, A. A. and Whitt, D. D.: Yersinia infections. Bacterial Pathogenesis: A molecular approach. p. 213-228, American Society for Microbiology Press, Washington. D. C. (1994).

43) Uchida, I., Kaneko, K. and Hashimoto, N.: Crossprotection against fecal excretion of Yersinia enterocolitica and Yersinia pseudotuberculosis in mice by oral vaccination of viable cells. Infect. Immun., 36, 837-840 (1982).

44) Uchiyama, T, Miyoshi-Akiyama, T., Kato, H., Fujimaki, W., Imanishi, K. and Yan, X. J.: Superantigenic properties of a novel migtogenic substance produced by Yersinia pseudotuberculosis isolated from patients manifesting acute and systemic symptoms. J. Immunol., 151, 4407-4413 (1993).

45) Wauters, G., Janssens, M., Steigerwalt, A. G. and Brenner, D. J.: Yersinia mollaretii sp. nov. and Yersinia bercovieri sp. nov., formerly called Yersinia enterocolitica biogroups $3 \mathrm{~A}$ and 3B. Int. J. Syst. Bacteriol., 38, 424-429 (1988).

46) Wren, B. W. and Tabaqchali, S.: Detection of pathogenic Yersinia enterocolitica by the polymerase chain reaction. Lancet, 336, 693 (1990).

47) Yanagawa, Y., Maruyama, T. and Sakai, S.: Isolation of Yersinia enterocolitica and Yersinia pseudotuberculosis from apparently healthy dogs and cats. Microbiol. Immunol., 22, 643-646 (1978).

48) Yersin, A.: La peste bubonique a Hong-kong. Ann. Inst. Pastur., 2, 428-430 (1894). 